\title{
Water Governance, Stakeholder Engagement, and Sustainable Water Resources Management
}

\author{
Sharon B. Megdal ${ }^{1, *}$, Susanna Eden ${ }^{1}$ and Eylon Shamir ${ }^{2}$ \\ 1 Water Resources Research Center, The University of Arizona, Tucson, AZ 85719, USA; \\ seden@email.arizona.edu \\ 2 Hydrologic Research Center, 11440 West Bernardo Court, Suite 375, San Diego, CA 92127, USA; \\ eshamir@hrcwater.org \\ * Correspondence: smegdal@email.arizona.edu; Tel.: +1-520-621-9591; Fax: +1-520-892-8518
}

Academic Editor: Arjen Y. Hoekstra

Received: 3 February 2017; Accepted: 2 March 2017; Published: 6 March 2017

\begin{abstract}
Water governance and stakeholder engagement are receiving research attention for their role in formulating and implementing solutions to the world's critical water challenges. The inspiration for this Special Issue came from our desire to provide a platform for sharing results and informing the global water governance community about the wealth of excellent interdisciplinary and transdisciplinary research and projects being carried out around the world. The 20 peer-reviewed papers collected in this Special Issue have been grouped into three categories: stakeholder engagement, tools for building water management and governance capacity, and perspectives on water management and governance. Following a brief summary of the papers, concluding remarks that reflect on what the papers, taken as a whole, contribute to our understanding are provided.
\end{abstract}

Keywords: water governance; stakeholder engagement; water management; water resources; participation; collaboration; groundwater; water sustainability

\section{Introduction}

The role of water governance and stakeholder engagement in formulating and implementing solutions to the world's critical water challenges is receiving increasing attention. Over the past several years, United Nations organizations, the World Bank, the Global Environmental Facility, the Organisation for Economic Co-operation and Development (OECD), and others have joined forces with governmental, academic, professional association, Non-Governmental Organization (NGO), and other private sector representatives to explore efforts to improve water governance [1-3]. These efforts and water projects at multiple geographic scales point to the value of sharing experiences and lessons learned so that good practices can be transferred. They also point to the criticality of engaging stakeholders in deliberations on alternative approaches to addressing water scarcity, water quality, and water sanitation issues.

Because good water governance and effective stakeholder engagement are inextricably linked, we assembled this journal's Special Issue on water governance, stakeholder engagement, and sustainable water resources management to provide a platform for sharing results and informing the global water governance community. The robust response to our invitation to authors and the open call for papers is evidence of the wealth of excellent interdisciplinary and transdisciplinary research and projects from around the world. Twenty peer-reviewed papers were selected for this Special Issue. We have grouped these papers into three categories: stakeholder engagement, tools for building water management and governance capacity, and perspectives on water management and governance. Although there are overlaps among these three groups, papers were assigned to each category based on the nature of 
their primary focus: the development and impact of stakeholder participation, the development and use of tools for improving the water governance process, or specific aspects of the sustainable water management domain. The first group includes papers that present issues in stakeholder engagement through various case studies. The focus in the second group is on specific tools that were employed in order to raise the level of communication and understanding in the water governance context. The third group includes papers that examine water resources governance from different points of view.

After we summarize the contributions according to this categorization, we provide some concluding remarks.

\section{Contributed Papers}

\subsection{Stakeholder Engagement}

A substantial group of contributed papers addressed best practices for stakeholder engagement as a key element in good water governance. A great deal of innovative work has been directed at learning from the practice of stakeholder engagement to address challenges such as identifying the approaches and methods that should be used under different circumstances to produce the desired results. Guidance for engaging stakeholders is sorely needed as every day new efforts are initiated that would benefit from analysis of evidence from previous experience. The paper by Mott Lacroix and Megdal, "Explore, Synthesize, and Repeat: Unraveling Complex Water Management Issues through the Stakeholder Engagement Wheel", proposes a framework for understanding and developing effective stakeholder engagement [4]. Based on case studies at a range of scales in Arizona, USA, the authors developed the Stakeholder Engagement Wheel to visualize and highlight the need for flexibility and an iterative process for reaching common water goals. The Wheel demonstrates the value of a bridging organization to structure the process and a steering committee to guide it. The paper discusses four challenges that engagement processes are likely to experience, which are paucity of time, complexity of water resources management, difficulty of engaging diverse stakeholders, and lack of methods for engagement that are centered on empowerment, equity, trust, and learning.

Beyond lessons learned, general principles are being teased out of experiences with engaging stakeholders in water management and governance. For example, Akhmouch and Clavreul emphasize inclusiveness as a prerequisite to successful water governance along with process and structure requirements. In "Stakeholder Engagement for Inclusive Water Governance: 'Practicing What We Preach' with the OECD Water Governance Initiative", the authors refer to the experience of the OECD Water Governance Initiative to provide guidance on the practice of inclusive stakeholder engagement from an evidence-based assessment of its contributions to achieving water governance goals [5]. Their conclusions are consonant with the guidance provided by Mott Lacroix and Megdal on the importance of consistent ongoing communication among participants and institutional support in the form of facilitation, coordination, and continuity by organizations promoting good water governance processes [4].

The collaborative processes can make or break planning and implementation of water management, as illustrated by Dillon et al. in "Community Perspective on Consultation on Urban Stormwater Management: Lessons from Brownhill Creek, South Australia". The authors take the perspective of a community group to evaluate and draw lessons from two community consultation processes, separated by four years, addressing the same stormwater problem for a watershed in Adelaide, South Australia, Australia [6]. The first was a failure, due in large part to the mishandling of the consultative process, while the second was a success, which the authors attribute to the process of community engagement. Early and transparent consultation, inclusiveness, and responsiveness were found to be important characteristics of engaging communities in decisions.

Stakeholder engagement in water management is often fraught with conflict when interest differences lead to mistrust and noncooperation. A significant component of stakeholder engagement, 
therefore, may involve techniques for reducing conflict. In "Conflict Management in Participatory Approaches to Water Management: A Case Study of Lake Ontario and the St. Lawrence River Regulation", Furber et al. examine the ability of the participatory "Shared Vision Planning" approach to resolve conflicts in efforts to develop a new water regulation plan for the Lake Ontario and St. Lawrence River area [7]. They conclude that the approach succeeded when stakeholders perceived that they had something to gain from collaboration, but failed with stakeholders who perceived any change as a loss.

Even where interest conflicts are not a significant factor, stakeholder engagement can improve the efficiency of water management. This is especially true where unique contexts make the application of standard management practices problematic. An example provided in this collection, "Using a Participatory Stakeholder Process to Plan Water Development in Koraro, Ethiopia" (Alfredo et al.), demonstrates that the use of a one-day participatory workshop structured to learn from stakeholders in Koraro, Ethiopia, about their understanding, relations, and preferences with respect to their water supply provided the foundation for more effective interventions than a prescriptive one-size-fits-all approach [8]. Methods such as workshops were found successful in eliciting important stakeholder preferences that have an impact on water resources management [9].

The success of stakeholder engagement itself, however, may depend on prior knowledge of context in order to approach stakeholders with sensitivity. This is explicitly the case when working with Tribal Nations in the USA. In "Engaging Southwestern Tribes in Sustainable Water Resources Topics and Management", Chief et al. focus specifically on the requirements for effective stakeholder engagement with Native American tribes of the southwestern USA, evaluating five case studies of collaborations in terms of four simple rules for engaging tribes in research: "Ask about ethics, do more listening, follow tribal research protocols, and give back to the community" [10].

\subsection{Tools for Building Water Management and Governance Capacity}

The governance capacity of stakeholders can be enhanced through processes specifically designed to promote learning and to build competence in understanding the system they want to govern. The needed system learning does not always emerge from collaboration processes: the quality of the process is important. In "Public Participation in Water Planning in the Ebro River Basin (Spain) and Tucson Basin (Arizona, USA): Impact on Water Policy and Adaptive Capacity Building", Ballester and Mott Lacroix compare case studies on the Ebro Basin in Spain and the Tucson Active Management Area in Arizona, USA, to determine the factors with significant influence on outcomes of participatory processes [11]. They found that while policy impacts depended largely on contextual factors, an increase in adaptive capacity was related to the quality of the participatory process.

It is a given that sustainable water governance requires shared systems knowledge [12]. Failures of participation to increase capacity have led investigators to search for effective tools to create knowledge. Stakeholder engagement in modeling has been used in many instances and has been successful in creating a shared knowledge base [13]. King and Thornton explore the potential of collaborative modeling in "Staying the Course: Collaborative Modeling to Support Adaptive and Resilient Water Resource Governance in the Inland Northwest" [14]. As a method that encourages conversation, relationships, integrated systems thinking, and scientific understanding, it provides a foundation on which to develop adaptive and resilient water governance. The authors make this argument based on the examples of work done in the Spokane River Basin and the Palouse Basin in the northwestern USA.

Another example of model use in creating knowledge is examined in "Opening the Black Box: Using a Hydrological Model to Link Stakeholder Engagement with Groundwater Management" by Eden et al. [15]. The authors explore how governance of complex groundwater systems will benefit from the co-production of knowledge about the system. A case of hydrologic model refinement and use to inform groundwater management in the Upper Santa Cruz River Basin in Arizona, USA, demonstrated how knowledge was co-produced through two-way communication between scientists and stakeholders that focused on generating an understanding of the workings of the model, hydrologic system, and management information needs. 
Other tools are being tested for their efficacy in achieving the desired learning goal. "Exploring the Potential Impact of Serious Games on Social Learning and Stakeholder Collaborations for Transboundary Watershed Management of the St. Lawrence River Basin" is one example [16]. Medema et al. interviewed stakeholders in the transboundary St. Lawrence River Basin to determine the extent of social learning that has occurred through stakeholder collaborations and reviewed the literature of serious games, proposing such games as a means for increasing social learning. Very little social learning was found and a number of barriers were identified, such as limited interaction between stakeholders and an uneven understanding of the issues, which the use of serious games may help to overcome.

Also in the category of capacity-building tools are systems that coordinate multiple levels of decision-making for integrated responses to demands. The development of these systems can require high levels of collaboration among stakeholders whose interactions have been constrained. A shared tool can overcome such constraints as is the case described in "International Severe Weather and Flash Flood Hazard Early Warning Systems-Leveraging Coordination, Cooperation, and Partnerships through a Hydrometeorological Project in Southern Africa" [17]. Jubach and Tokar describe a project in Southern Africa intended to coordinate severe weather and flood warning systems at multiple levels by multiple responsible organizations. Linkages and interfaces will be established and strengthened through development of a roadmap of activities and a concept of operation that lays out the requirements for routine forecasts and operations during unusual events.

\subsection{Perspectives on Water Management and Governance}

Water management and governance have many facets that shed light on the topic from different angles. The final section of this Special Issue contains papers written from a range of perspectives from law to economics, culture, and social justice.

How does public opinion affect the achievement of water management goals and what influences public opinion to support or reject those goals? These are questions addressed in "Undermining Demand Management with Supply Management: Moral Hazard in Israeli Water Policies" by Katz [18]. He argues that care must be taken when communicating with the public about the solutions to water scarcity: over-confidence in augmentation strategies can undermine public belief in the need for conservation. He concludes that desalination was oversold to the public as the solution to Israel's water problems, causing a general increase in water use although water scarcity continues to be an issue.

Cosens and Chaffin focus on the particular challenges for indigenous peoples in establishing rights to water. "Adaptive Governance of Water Resources Shared with Indigenous Peoples: The Role of Law" examines the influence of law on the emergence of adaptive governance that is capable of responding to new pressures, specifically the assertion of water rights by Native Americans and the Ngarrindjeri Nation in Australia [19]. They find that legal tools can provide the catalyst for the development of adaptive processes, build institutions that solidify these processes, and legitimize their results.

Focusing on the law with respect to groundwater, Mechlem takes a global perspective to her examination of its evolution, as the importance of groundwater is increasingly recognized. In "Groundwater Governance: The Role of Legal Frameworks at the Local and National Level-Established Practice and Emerging Trends", she notes that groundwater legislation is being developed that balances inherent uncertainty about availability and quality with the need for certainty about rights to water use [20]. These legal frameworks reflect context-based groundwater governance that accounts for the unique conditions of each country.

Groundwater management and governance face challenges specific to the nature of the resource as hidden from sight and difficult to assess in terms of amount, accessibility, quality, renewability, etc. [21]. As Mechlem and others have noted, contextual factors are the dominant influences on how groundwater is governed [20]. This finding was affirmed by Varady et al. from multiple, diverse 
case studies in "Modes and Approaches of Groundwater Governance: A Survey of Lessons Learned from Selected Cases across the Globe" [22]. The paper provides an integrated review of 10 carefully selected case studies of groundwater governance from across the globe, representing diverse local contexts. To a large extent, these contexts determined governance policy. Despite the contextual diversity, however, they synthesized a number of lessons across cases relating to four elements of groundwater governance: an institutional setting, access to science and information, the robustness of civil society, and economic and regulatory frameworks. Among other lessons, the authors note the need for research to support policy development.

The need for research is frequently highlighted as data and information are often lacking for groundwater systems. As a result, decision-makers are often unaware of all the factors affecting policy impacts. In a comprehensive review of what should be considered in order to effectively govern groundwater, van der Gun et al. make connections often overlooked with related subsurface resources including space for aquifer storage [23]. "Enhancing Groundwater Governance by Making the Linkage with Multiple Uses of the Subsurface Space and Other Subsurface Resources" describes the many uses of the subsurface and their impacts on groundwater resources to highlight the need for much greater awareness and integration of policies and practices relating to other subsurface uses.

Wastewater offers a context for examining the relation of centralized governance with efforts to achieve management goals at the local level. Flores et al. use their Governance Assessment Tool to analyze the implementation of wastewater treatment policies in the Tlaxcala Atoyac Sub-Basin in Mexico in "Water Governance Decentralisation and River Basin Management in Hierarchical Systems: Do They Work in Mexico's Tlaxcala Atoyac Sub-Basin?" [24]. Use of the tool allowed them to evaluate efforts to decentralize governance with respect to meeting wastewater treatment goals and find the failure of these efforts in lack of policy responsibility and resources by local authorities. The historical and political context of Mexico's centralized governing institutions had a decisive influence on attempts to decentralize water treatment, putting a damper on change. Institutional and cultural context also can determine the how policy is made and implemented, as shown by Golan in "The Fall and Rise of the Kishon River" [25]. He uses the history of the Kishon River in Israel to highlight the cultural and ideological influences on policy decisions and actions that allowed the river to be sacrificed to development and later drove its rehabilitation. Thus the change to a more sustainable regime was hampered and then promoted by cultural attitudes.

A key question in water policy-making relates to how benefits of a particular policy are counted. When economic benefits are paramount, other benefits are likely to be discounted with on-the-ground results on undervalued sectors. In "Water and Agriculture in a Mediterranean Region: The Search for a Sustainable Water Policy Strategy", Llop and Ponce-Alifonso used a computable general equilibrium model to examine the impacts of technological change and the principle of cost recovery for water service on economic efficiency, environmental sustainability, and political viability in Catalonia, Spain [26]. They conclude that there are tradeoffs among these goals that require agricultural and water policies, now aimed at increasing efficiency, to focus more broadly on strategies for reducing environmental and political costs.

Ignoring the consequences of a focus on economic efficiency can drive policies that undermine the condition of the poor. Sustainable water governance comprehends the justice of policies and actions and their impacts on all stakeholders [27]. In "Re-Linking Governance of Energy with Livelihoods and Irrigation in Uttarakhand, India", Buechler et al. investigated the impacts of hydropower projects on rural communities in order to derive recommendations to improve the social justice of energy development governance [28]. They conclude that governance instruments can be employed to compensate rural losses and share the benefits of hydropower projects more equitably.

\section{Conclusions}

Taken as a whole, the contributions to this Special Issue reinforce several messages from the rich study of collaboration in water management and governance. As stated repeatedly in 
these papers, context matters. Stakeholder engagement is an important tool in developing the common understanding of context that is necessary for making decisions that affect sustainable water management. Context also matters for effective stakeholder engagement, so it must occur over time, leaving space to develop and change. Research and lessons from the experience of others can help provide a foundation for engagement actions that promote mutual learning, but iterative interaction among the participants is needed for dealing with water resource management for the long term. The specific form this will take depends on context.

Another theme threaded throughout these papers is the importance of legal, regulatory, and institutional frameworks in supporting or hindering the development of governance for sustainable water management. Frameworks that lack clear engagement goals or represent a restricted set of interests can limit participation to the detriment of management and governance processes and outcomes. On the other hand, frameworks can be catalysts for action. They can support processes that bridge interest divides and resolve conflicts and can be a source of forward momentum for the planning and implementation of water management and governance strategies.

The need for holistic approaches was invoked several times to comprehend the complex and interlinked aspects of water governance and management. Water management and governance issues comprise many dynamically related components, which can only be adequately addressed by understanding their interconnections. Parties engaged in water resource problem solving are advised to examine the boundaries of the water governance issue being addressed. This examination can reveal interests, relationships, and physical, social, political, and cultural influences that may be excluded to the detriment of both the process and outcomes.

This collection of papers is a resource for insights and guidance on developing effective and sustainable water governance at a range of scales from global principles to practical local actions. It was assembled to display the breadth of research that has been inspired by the need to improve water management sustainability, promote effective water governance, and foster successful stakeholder engagement in vital decisions about water. As the importance of stakeholder engagement in water governance issues has been widely recognized, we believe that there is an essential need for scientific publication outlets that present varieties of case studies and discuss best practices. We hope that this Special Issue will serve as a template to encourage future research that improves stakeholder engagement and water governance and promotes sustainable water management.

Author Contributions: Sharon B. Megdal conceived and led development of the paper; Sharon B. Megdal, Susanna Eden and Eylon Shamir each contributed substantially to the writing of the paper.

Conflicts of Interest: The authors declare no conflict of interest.

\section{References}

1. Transboundary Water Assessment Programme. Available online: http:/ /www.geftwap.org/ (accessed on 30 January 2017).

2. Groundwater Governance-A Global Framework for Action. Available online: http://www. groundwatergovernance.org/home/en/ (accessed on 30 January 2017).

3. OECD Water Governance Initiative. Available online: http://www.oecd.org/gov/regional-policy/watergovernance-initiative.htm (accessed on 30 January 2017).

4. Mott Lacroix, K.E.; Megdal, S.B. Explore, Synthesize, and Repeat: Unraveling Complex Water Management Issues through the Stakeholder Engagement Wheel. Water 2016, 8, 118. [CrossRef]

5. Akhmouch, A.; Clavreul, D. Stakeholder Engagement for Inclusive Water Governance: "Practicing What We Preach" with the OECD Water Governance Initiative. Water 2016, 8, 204. [CrossRef]

6. Dillon, P.; Bellchambers, R.; Meyer, W.; Ellis, R. Community Perspective on Consultation on Urban Stormwater Management: Lessons from Brownhill Creek, South Australia. Water 2016, 8, 170. [CrossRef]

7. Furber, A.; Medema, W.; Adamowski, J.; Clamen, M.; Vijay, M. Conflict Management in Participatory Approaches to Water Management: A Case Study of Lake Ontario and the St. Lawrence River Regulation. Water 2016, 8, 280. [CrossRef] 
8. Alfredo, K.; Montalto, F.A.; Bartrand, T.; Wolde-Georgis, T.; Lall, U. Using a Participatory Stakeholder Process to Plan Water Development in Koraro, Ethiopia. Water 2016, 8, 275. [CrossRef]

9. Phillipson, J.; Lowe, P.; Proctor, A.; Ruto, E. Stakeholder engagement and knowledge exchange in environmental research. J. Environ. Manag. 2012, 95, 56-65. [CrossRef] [PubMed]

10. Chief, K.; Meadow, A.; Whyte, K. Engaging Southwestern Tribes in Sustainable Water Resources Topics and Management. Water 2016, 8, 350. [CrossRef]

11. Ballester, A.; Mott Lacroix, K.E. Public Participation in Water Planning in the Ebro River Basin (Spain) and Tucson Basin (Arizona, USA): Impact on Water Policy and Adaptive Capacity Building. Water 2016, 8, 273. [CrossRef]

12. Van Rijswick, M.; Edelenbos, J.; Hellegers, P.; Kok, M.; Kuks, S. Ten building blocks for sustainable water governance: An integrated method to assess the governance of water. Water Int. 2014, 39, 725-742. [CrossRef]

13. Voinov, A.; Bousquet, F. Modelling with stakeholders. Environ. Model. Soft 2010, 25, 1268-1281. [CrossRef]

14. King, A.B.; Thornton, M. Staying the Course: Collaborative Modeling to Support Adaptive and Resilient Water Resource Governance in the Inland Northwest. Water 2016, 8, 232. [CrossRef]

15. Eden, S.; Megdal, S.B.; Shamir, E.; Chief, K.; Mott Lacroix, K. Opening the Black Box: Using a Hydrological Model to Link Stakeholder Engagement with Groundwater Management. Water 2016, 8, 216. [CrossRef]

16. Medema, W.; Furber, A.; Adamowski, J.; Zhou, Q.; Mayer, I. Exploring the Potential Impact of Serious Games on Social Learning and Stakeholder Collaborations for Transboundary Watershed Management of the St. Lawrence River Basin. Water 2016, 8, 175. [CrossRef]

17. Jubach, R.; Tokar, A.S. International Severe Weather and Flash Flood Hazard Early Warning Systems-Leveraging Coordination, Cooperation, and Partnerships through a Hydrometeorological Project in Southern Africa. Water 2016, 8, 258. [CrossRef]

18. Katz, D. Undermining Demand Management with Supply Management: Moral Hazard in Israeli Water Policies. Water 2016, 8, 159. [CrossRef]

19. Cosens, B.; Chaffin, B.C. Adaptive Governance of Water Resources Shared with Indigenous Peoples: The Role of Law. Water 2016, 8, 97. [CrossRef]

20. Mechlem, K. Groundwater Governance: The Role of Legal Frameworks at the Local and National Level-Established Practice and Emerging Trends. Water 2016, 8, 347. [CrossRef]

21. Alley, W.M.; Beutler, L.; Campana, M.E.; Megdal, S.B.; Tracy, J.C. Groundwater Visibility: The Missing Link. Groundwater 2016, 54, 758-761. [CrossRef] [PubMed]

22. Varady, R.G.; Zuniga-Teran, A.A.; Gerlak, A.K.; Megdal, S.B. Modes and Approaches of Groundwater Governance: A Survey of Lessons Learned from Selected Cases across the Globe. Water 2016, 8, 417. [CrossRef]

23. Van der Gun, J.; Aureli, A.; Merla, A. Enhancing Groundwater Governance by Making the Linkage with Multiple Uses of the Subsurface Space and Other Subsurface Resources. Water 2016, 8, 222. [CrossRef]

24. Flores, C.C.; Vikolainen, V.; Bressers, H. Water Governance Decentralisation and River Basin Management in Hierarchical Systems: Do They Work in Mexico's Tlaxcala Atoyac Sub-Basin? Water 2016, 8, 210. [CrossRef]

25. Golan, T. The Fall and Rise of the Kishon River. Water 2016, 8, 283. [CrossRef]

26. Llop, M.; Ponce-Alifonso, X. Water and Agriculture in a Mediterranean Region: The Search for a Sustainable Water Policy Strategy. Water 2016, 8, 66. [CrossRef]

27. Schneider, F.; Bonriposi, M.; Graefe, O.; Herweg, K.; Homewood, C.; Huss, M. Assessing the sustainability of water governance systems: The sustainability wheel. J. Environ. Plan. Manag. 2015, 58, 1577-1600. [CrossRef]

28. Buechler, S.; Sen, D.; Khandekar, N.; Scott, C.A. Re-Linking Governance of Energy with Livelihoods and Irrigation in Uttarakhand, India. Water 2016, 8, 437. [CrossRef]

(C) 2017 by the authors. Licensee MDPI, Basel, Switzerland. This article is an open access article distributed under the terms and conditions of the Creative Commons Attribution (CC BY) license (http:/ / creativecommons.org/licenses/by/4.0/). 